DOI: 10.32089/WBH.PHW.2020.4(274).0006

orcid.org/0000-0002-1625-1926

ANDRZEJ GtadysZ

(Katolicki Uniwersytet Lubelski Jana Pawła II)

\title{
Rejestr dworzan konnych Zygmunta I Starego wysłanych do walki z Krzyżakami pustoszącymi Mazowsze na przełomie lipca i sierpnia 1520 roku
}

Badania nad dworami monarszymi w szesnastowiecznej Polsce mają ugruntowaną pozycję. W ciągu ostatnich dwóch dekad ukazały się monograficzne opracowania dworów Zygmunta Augusta, Aleksandra Jagiellończyka, Jana Olbrachta oraz szereg artykułów naukowych z zakresu kultury, obyczajowości czy religijności dworskiej¹. Poruszono również kwestię dworów królewskich małżonek Zygmunta Augusta ${ }^{2}$.

Zdecydowanie mniej uwagi historycy poświęcili badaniu dworu królewskiego ostatnich Jagiellonów w kontekście wojskowości, które to zagadnienie w dorobku najbardziej zasłużonego badacza polskiej wojskowości renesansowej, Marka Plewczyńskiego, stanowiły aspekt marginalny³. Szczegółowe

\footnotetext{
${ }^{1}$ Zob. m.in. M. Ferenc, Dwór Zygmunta Augusta. Organizacja i ludzie, Kraków 1998; zob. także: idem, Uwagi o dworze litewskim Zygmunta Augusta w latach 1548-1572 [w:] Ecclesia - cultura - potestas. Studia z dziejów kultury i społeczeństwa. Ksiega ofiarowana Siostrze Profesor Urszuli Borkowskiej OSU, red. P. Kras et al., Kraków 2006, s. 537-548; J. Skibniewska, Dwór królewski Aleksandra Jagiellończyka w latach 1501-1506, Lublin 2015; A. Nalewajek, Na królewskim dworze Jana Olbrachta, „Roczniki Humanistyczne” 2011, t. 59, s. $41-77$.

${ }^{2}$ A. Marchwińska, Królewskie dwory żon Zygmunta Augusta. Organizacja i składy osobowe, Toruń 2008.

${ }^{3}$ Kwestie wojskowości dworskiej bardzo ogólnie omówione zostały przez Marka Plewczyńskiego, zob. idem, Wojny i wojskowość polska w XVI wieku, t. 1: Lata 1500-1548, Zabrze 2011, s. 19-20; idem, Wojny i wojskowość polska XVI wieku, t. 2: Lata 1548-1575, wyd. 2, Oświęcim 2018, s. 13.
} 
zainteresowanie wojskowością dworską Zygmunta Augusta wykazał Marek Ferenc $^{4}$. Zagadnienia te były kontynuowane przez autora niniejszego tekstu, najpierw w szkicach związanych z wojskowością ostatniego Jagiellona ${ }^{5}$, a następnie jego ojca ${ }^{6}$.

Dla celów komparatystycznych pomocne okazały się prace historyków wojskowości obejmujące zagadnienia funkcjonowania militarnego dworu w okresie poprzedzającym panowanie ostatnich Jagiellonów ${ }^{7}$, jak również w czasach pierwszych królów elekcyjnych ${ }^{8}$.

Poszerzenie wiedzy na temat wojskowej aktywności dworu Zygmunta I Starego jest możliwe dzięki kwerendzie źródłowej przeprowadzonej w licznie zgromadzonych materiałach archiwalnych. Wśród nich, z perspektywy badań nad wojskowością, szczególne znaczenie ma zespół Archiwum Skarbu Koronnego (ASK) przechowywany w Archiwum Głównym Akt Dawnych (AGAD)

${ }^{4}$ M. Ferenc, Stużba wojskowa dworzan króla Zygmunta Augusta [w:] Dwór a kraj. Między centrum a peryferiami władzy. Materiały konferencji naukowej zorganizowanej przez Zamek Królewski na Wawelu, Instytut Historii Uniwersytetu Jagiellońskiego, Instytut Historii Akademii Pedagogicznej w Krakowie w dniach 2-5 kwietnia 2001, red. R. Skowron, Kraków 2003, s. 99-116.

${ }^{5}$ A. Gładysz, Wyprawa pozwolska Zygmunta Augusta w 1557 roku, „Roczniki Humanistyczne" 2008, t. 56, z. 2: Historia, s. 81-107; idem, Armia Zygmunta Augusta w wyprawie inflanckiej 1557 roku - źródła a historiografia [w:] Broń i wojna w dziejach człowieka, red. K. Badowska, W. Wasiak, P. Łuczak, Łódź [2009], s. 207-212; idem, Wojskowe osiągnięcia Zygmunta Augusta. Próba oceny [w:] Sigismundus Augustus Rex. Studia i szkice z dziejów panowania ostatniego Jagiellona, red. A. Januszek-Sieradzka, Sandomierz 2010, s. 149-166, (=„Praeclara stirps Jagiellonica”, t. 2); idem, Wojskowi ulubieńcy Zygmunta Augusta, czyli o królewskich puszkarzach, ich jadłospisie i tajemniczej „skrzynce” [w:] Servitium et amicitia. Studia $z$ dziejów kariery i awansu w Polsce Jagiellonów, red. A. Januszek-Sieradzka, Sandomierz 2011, s. 119-143, (=„Praeclara stirps Jagiellonica”, t. 3).

${ }^{6}$ Idem, Jedna, czy dwie choragwie nadworne Zygmunta I w kampanii mołdawskiej 1509 r.? [w:] Na z góry upatrzonych pozycjach, red. B. Międzybrodzki et al., Zabrze 2011, s. 93-103; idem, Dworzanie Zygmunta I w wojnie z Mołdawia (1530-1532) [w:] Spes in virtute. Salus in victoria, red. J. Gładysz, D. Lipska, A. Gładysz, Zabrze 2013, s. 58-76; idem, Militarne aspekty funkcjonowania dworu królewskiego ostatnich Jagiellonów - stan badań i ich perspektywy [w:] Ad perpetuam rei memoriam. Jagiellonowie i ich czasy w historiografii polskiej XVI-XXI wieku, red. A. Januszek-Sieradzka, Sandomierz 2013, s. 37-57, (=,Praeclara stirps Jagiellonica”, t. 4); idem, „Służba wojskowa dworzan Zygmunta I Starego”, Lublin 2014, s. 185,211 , mps pracy doktorskiej w zbiorach autora.

${ }^{7}$ J. T. Kałużny, U boku króla. Chorąiew nadworna królów Polski u schyłku XV wieku, „Acta Universitatis Lodziensis. Folia Historica” 2019, nr 13, s. 59-72; A. Bołdyrew, Uzbrojenie wczesnonowożytnego dworu książęcego w świetle rachunków dworskich. Analiza porównawcza, „Kwartalnik Historii Kultury Materialnej” 2009, nr 1, s. 3-18.

${ }^{8}$ D. Kadzik, „Wojsko nadworne” na początku wojny Stefana Batorego z Gdańskiem w świetle akt skarbowych, „Przegląd Historyczno-Wojskowy” 2017, nr 1 (259), s. 9-43. 
w Warszawie, składający się z 12 serii, stanowiących pozostałość po polskiej administracji skarbowej, w tym późnośredniowiecznej i renesansowej9.

Prezentowane w niniejszym szkicu źródło to niewielki fragment $\mathrm{z}$ obszernej sygnatury 49 zespołu ASK - Oddział 1 (Rachunki królewskie). Cała księga o wymiarach $22 \times 32 \mathrm{~cm}$ liczy 109 kart, z czego 30 stron pozostało niezapisanych ${ }^{10}$. Jako element składowy „Rachunków królewskich” zawiera informacje skarbowe związane z działalnością dworu między 1519 a $1521 \mathrm{r}$. Powstała w kręgu działalności kancelarii podskarbińskiej ${ }^{11}$. Na obecnym etapie badań niemożliwe jest ustalenie autorstwa dokumentu, który stanowi wykaz wydatków, sporządzany zapewne na bieżąco ${ }^{12}$. Z perspektywy badań wojskowości dworu szczególne znaczenie mają zamieszczone w księdze rejestry dworzan konnych z pocztami, kierowanych do działań zbrojnych ${ }^{13}$.

Prezentowany w niniejszym szkicu wycinek, podobnie jak cały rękopis, nie były dotychczas publikowane. Łaciński tekst renesansowy podano zgodnie z przyjętymi zasadami edytorskimi dla źródeł nowożytnych, dokonano

${ }^{9}$ Archiwum Główne Akt Dawnych (dalej: AGAD), Archiwum Skarbu Koronnego (dalej: ASK), Oddział 1 (Rachunki Królewskie); Oddział 2 (Rachunki Poselstw); Oddział I (Rejestry Podatkowe); Oddział II (Rachunki Sejmowe); Oddział III (Rachunki Nadworne); Oddział IV (Księgi Rekognicji); Oddział V (Księgi Kwitów); Oddział VI (Księgi Asygnat); Oddział XLVI (Lustracje, rewizje i inwentarze dóbr królewskich); Oddział LIV (Zbiór pism rozmaitych tyczących się dóbr królewskich), Oddział LVI (Inwentarze dóbr królewskich); Oddział 82 (Zbiór pism rozmaitych wydziału wojskowego dotyczących); Oddział 84 (Księgi addytamentów wojskowych); Oddział 85 (Rejestry popisowe wojska koronnego); Oddział 86 (Rachunki z przychodów i wydatków na potrzeby wojska).

${ }^{10}$ Wykaz kart niezapisanych: $6 \mathrm{v}, 8 \mathrm{v}, 9 \mathrm{v}-10 \mathrm{v}, 11 \mathrm{v}, 12 \mathrm{v}, 13 \mathrm{v}, 60,66 \mathrm{v}-69 \mathrm{v}, 74-75 \mathrm{v}, 84 \mathrm{v}-85$, $105 \mathrm{v}, 106 \mathrm{v}-109 \mathrm{v}$.

${ }^{11}$ Przy czym należy zaznaczyć, że co najmniej do 1539 r. pisarze urzędu podskarbińskiego byli ściśle związani z kancelarią królewską. J. Senkowski, Rachunki królewskie $i$ Rachunki sejmowe [w:] Archiwum Główne Akt Dawnych. Przewodnik po zespołach, wyd. 2 popr. i rozsz., red. J. Karwasińska, Warszawa 1975, s. 119-120; I. Sułkowska-Kurasiowa, Polska kancelaria królewska w latach 1447-1506, Wrocław 1967, s. 36, passim. O działalności kancelarii królewskiej zob. m.in.: W. Chorążyczewski, Przemiany organizacyjne polskiej kancelarii królewskiej u progu czasów nowożytnych, Toruń 2007; idem, Sprawy wojskowe w kancelarii królewskiej Zygmunta Starego, Warszawa 2001, s. 69-80, (=„Miscellanea Historico-Archivistica”, t. 13); A. Wyczański, O potrzebie badań nad kancelarią Zygmunta Starego (1506-1548) [w:] Historia i archiwistyka. Ksiega pamiątkowa ku czci profesora Andrzeja Tomczaka, red. J. Dygała et al., Warszawa 1992, s. 147-152; idem, Między kulturą a polityką. Sekretarze królewscy Zygmunta Starego (1506-1548), Warszawa 1990.

${ }^{12}$ Za cenne dyskusje i uwagi na temat charakteru i okoliczności powstania dokumentacji finansowej dziękuję dr hab. Agnieszce Januszek-Sieradzkiej.

${ }^{13}$ Zwrócić należy uwagę na kwestię organizacji wojskowej dworzan konnych i sposobu formowania z nich chorągwi, niejednokrotnie kilku równocześnie, działających niezależnie od siebie. A. Gładysz, „Służba wojskowa dworzan...”, s. 41-50. Zagadnienie to jest tematem odrębnego studium przygotowywanego przez autora niniejszej edycji. 
uwspółcześnienia pisowni polsko brzmiących nazwisk ${ }^{14}$. W przypisach zamieszczono krótkie wykazy aktywności dworzan, zawierające dane o przebiegu ich kariery, ze szczególnym uwzględnieniem działalności dworskiej i militarnej.

Przedstawione źródło stanowi jeden z przykładów dysponowania wojskowym otoczeniem Zygmunta I. Otóż wynika z niego, że sformowana w końcu lipca 1520 r., niewielka chorągiew dworska w lipcu i sierpniu tr. została skierowana w rejon Prus Dolnych i północnego Mazowsza, gdzie podjęła odpowiednio działalność łupieżczą na ziemiach zakonnych i prewencyjną, ograniczając rabunki prowadzone przez zagony krzyżackie na własnym terenie. Grupa ta liczyła 69 koni w 15 pocztach. Średnia wielkość pocztu wynosiła zatem 4,60 konia.

Tabela 1. Poczty w chorągwi nadwornej wg wielkości (Mazowsze lipiec - sierpień 1520 r.)

\begin{tabular}{|c|c|}
\hline Wielkość pocztu & Liczba pocztów \\
\hline 7-konny & 2 \\
\hline 6-konny & 3 \\
\hline 5-konny & 3 \\
\hline 4-konny & 4 \\
\hline 2-konny & 3 \\
\hline
\end{tabular}

Źródło: oprac. własne autora

Zestawiając omawiany wykaz z rejestrami dworzan konnych służących na koniach kopijniczych i lekkozbrojnych (1518-1526) ${ }^{15}$, można pokusić się o analizę struktury chorągwi. Wynika z niej, że pięć z wymienionych pocztów

${ }^{14} \mathrm{~K}$. Lepszy, Instrukcja wydawnicza dla źródeł historycznych od XVI w. do poł. XIX w., Warszawa 1953.

${ }^{15}$ AGAD, ASK, Oddz. 85 (Rejestry popisowe wojska koronnego - dalej: Oddz. 85), sygn. 13: Regestrum equorum magnorum in quo numero aliquis curien [sibus] servit, inceptum Cracovie anno Domini 1518 a die sancti Blasii, quando equi omnes indempnes omnibus curiensibus, qui eos habebant, soluti erant et aliquibus equi in suo computo prori minorabantur et in minori de novo conscribebantur, ut processus regestri clarius ostendit (dalej: sygn. 13); sygn. 14: Regestrum equorum levis armaturae aliis evnuchorum in quo numero aliquis curiensibus servit, inceptum Cracovie anno Domini 1518 a die sancti Blasii, quando equi omnes indempnes omnibus, qui eos habebant solvit erat. Et aliquibus equi de suo [...] computo [...]. Et in minori numero de novo conscribebantur ut processus regestri clarus ac clarat et ostendit (dalej: sygn. 14). Trwają prace nad edycją krytyczną wspomnianych ksiąg, które są realizowane przez dr hab. Agnieszkę Januszek-Sieradzką oraz autora niniejszego szkicu w ramach grantu NPRH 0469/NPRH/H30/84/2017 „Epoka jagiellońska i jej dziedzictwo w I Rzeczypospolitej do 1795 roku. Źródła do dziejów wojskowości polskiej w epoce Jagiellonów" - kierownik prof. dr hab. Jan Szymczak. 
było popisanych na dworze jako kopijnicze ${ }^{16}$, a dziewięć jako lekkozbrojne ${ }^{17}$. Charakter pocztu Floriana Bierzwieńskiego pozostaje nieustalony, przy czym konfrontacja ze spisami chorągwi nadwornych z lat 1508 i 1530 wskazuje potencjalnie na służbę lekkozbrojną ${ }^{18}$.

Wobec powyższego można ostrożnie przyjąć, że chorągiew składała się w $33 \%$ z pocztów kopijniczych ${ }^{19}$, a w $66 \%$ z lekkozbrojnych, co pozwala wstępnie przypuszczać, iż chorągiew byłaby kwalifikowana do kopijniczych ${ }^{20}$. Tym niemniej informacje te dotyczą jedynie wojskowej klasyfikacji pocztów dworskich. Wnikliwa analiza ich składu pozwala stwierdzić, że w rzeczywistości liczba koni kopijniczych w wymienionych pocztach była znacznie niższa, wynosząc ok. $10 \%{ }^{21}$, co z kolei plasuje oddział w kategorii lekkozbrojnej konnicy. Jednakże, co do zasady, to nie typ konia, a uzbrojenie jeźdźca decydowało ostatecznie o charakterze służby. Tymczasem źródła proweniencji dworskiej, jakimi dysponujemy współcześnie, zupełnie nie poruszają spraw związanych z wyposażaniem dworzan-towarzyszy i ich pocztowych, walczących na wspomnianych wierzchowcach.

${ }^{16}$ Jana Dobrzykowskiego, Pawła Machały, Mikołaja Smolikowskiego, Wiktoryna Choteckiego i Jana Kempy.

${ }^{17}$ Andrzeja Załuchy, Strzeżowskiego, Jana Morawca, Szumlańskiego, Serafina Wronikowskiego, Jana Dzieraźnickiego i Jana Zajączka.

${ }^{18}$ W kampanii 1508 r. w Wielkim Księstwie Litewskim Bierzwieński z pocztem 4-konnym wchodził w skład wydzielonej chorągwi lekkozbrojnej w sile 62 koni (14 pocztów), która prowadziła działania wywiadowcze w pobliżu wojsk przeciwnika od 23 VI 1508 r. Z kolei jesienią 1530 r. uczestniczył w walkach z najazdem mołdawskim w hufcu dworskim liczącym ok. 500 koni z 4-konnym pocztem lekkim. Zob. A. Gładysz, „Służba wojskowa dworzan...”, s. $185,211$.

${ }^{19}$ U progu XVI w. w Polsce występują co do zasady dwa typy chorągwi: kopijnicze i strzelcze, przy czym „w pocztach kopijniczych zawsze znajduje się nieco strzelców, a wśród towarzyszy rot strzelczych nieco kopijników”; M. Kukiel, Zarys historii wojskowości w Polsce, Kraków 1929, s. 40. Należy przyjąć, że poczet kopijniczy to taki, w którym przynajmniej towarzysz walczył jako ciężkozbrojny, zaś w poczcie strzelczym również towarzysz mógł być pozbawiony kopii.

${ }^{20}$ Proporcje decydujące o klasyfikacji chorągwi jako kopijniczej, strzelczej lub lekkozbrojnej opisywał Marek Plewczyński, wskazując, że „liczebny stosunek ciężkozbrojnych kopijników i średniozbrojnych strzelców decydował o tym, czy chorągiew uznawano za kopijniczą, czy też strzelczą". Dla pierwszego typu plasował się on jak 1:2, zaś dla drugiego - 1:4. A zatem w chorągwi kopijniczej ok. 33\% zbrojnych winno być "gravioris armaturae”, podczas gdy w strzelczej odnotowywano zaledwie $20 \%$ ciężkozbrojnych. M. Plewczyński, Wojny i wojskowość polska..., t. 1, s. 49-50. Już Jan Tarnowski podkreślał, że mieszanie tych rodzajów jazdy jest celowe, „bo jedni bez drugich nie są tak pożyteczni, jak gdy tym oboim rynsztunkiem są". Cyt. za M. Kukiel, Zarys historii wojskowości..., s. 40.

${ }^{21}$ Mogła wynosić maksymalnie kilka koni na 69 biorących udział w wyprawie. AGAD, ASK, Oddz. 85, sygn. 13-14, passim. 
Na czele spisu widnieje Jan Dobrzykowski, być może „porucznik”, dowódca wyznaczony przez króla lub marszałka spośród dworzan biorących udział w tej ekspedycji, przynajmniej do czasu objęcia komendy przez Jakuba Secygniowskiego ${ }^{22}$, pod którego auspicja grupa została skierowana ${ }^{23}$. Na podstawie źródeł archiwalnych i literatury dokonano identyfikacji wszystkich dworzan wysłanych do Secygniowskiego. Zaledwie czterech z nich miało uprzednio związek z dworem monarszym ${ }^{24}$. Większość do grupy dworzan konnych zaciągnięto doraźnie, w zasadzie

${ }^{22}$ Secygniowski Jakub (ur. ? - zm. 22 VII 1530) - burgrabia krakowski 1494-1500, dworzanin królewski 1494-1500, dworzanin hospodarski 1500-1501 w 12-18 koni, dworzanin królewski 1501 r., rotmistrz niewielkiej chorągwi nadwornej 1502-1503 na Litwie, rotmistrz jazdy zaciężnej 1508 r., dworzanin Zygmunta I 1509-1523 w 5 koni, rotmistrz jazdy 1512 r., walczył z najazdem tatarskim 1512 r., walczył pod Wiśniowcem 28 IV 1512 r., poselstwo do Mołdawii 1513 r., rotmistrz chorągwi 200 koni w wojnie z Moskwą 1514 r., bił się pod Orszą 8 IX 1514 r., rotmistrz jazdy obrony potocznej 1516 r., walka z najazdem tatarskim 1516 r., potyczka pod Zinkowem 8 XII 1516 r., rotmistrz jazdy zaciężnej 1517 r., rotmistrz zaciężnej chorągwi husarii w sile 250 koni 1519 r. na Podolu, poselstwo do Turcji 1519 r., wojna pruska 1520 r., w składzie grupy Jakuba Rożnowskiego, Kwidzyn 14 II 1520 r., później naczelny dowódca wojsk polskich na Warmii, wypad na Bartoszyce, Pasłęk, Braniewo, ponowny zaciąg 300 koni (w tym 20 ciężkich), oblężenie Braniewa, Reszla, Rastemborka, 18 IX - listopad 1520 r. dzielna obrona oblężonego Lidzbarka Warmińskiego; hetman wojsk zaciężnych w Prusach 18 I 1521 r., Morąg, pościg za Albrechtem Hohenzollernem, Pasym, starosta buski przed 1521 r., najazd turecki 1524 r., rotmistrz jazdy obrony potocznej 1525 r., umocnienie murów Buska 1525 r., rotmistrz jazdy zaciężnej na Węgrzech 1528 r., dowódca wojsk węgierskich i 2 tys. Polaków u Jana Zapolyi 1528-1529, klęska pod Szina. Matricularum Regni Poloniae Summaria (dalej MRPS), wyd. T. Wierzbowski, cz. 4: Sigismundi I regis tempora complecens (1506-1548), t. 1, Warszawa 1917, nr 3585, 3861, 4102-4103, 4185, 4389, 4550, 4646, 4919; t. 2: nr 8852, 10818, 11897, 12649, 13117-13118, 13461, 13752, 14139, 14490-14491, 14515; M. Plewczyński, Materiały do zagadnienia liczebności i organizacji wojska polskiego w latach 1506-1572, „Studia i Materiały do Historii Wojskowości” (dalej SMHW) 1989, t. XXXI, s. 316, 318-320, 322, 324; cz. 3, SMHW 1990, t. XXXII, s. 259-260; M. Biskup, Polskie listy dowódców Zygmunta I $z$ Prus $z$ okresu wojny z Zakonem Krzyżackim (1519-1521) [w:] Kultura średniowieczna i staropolska. Studia ofiarowane Aleksandrowi Gieysztorowi w pięćdziesięciolecie pracy naukowej, red. D. Gawinowa et al., Warszawa 1991, s. 509-510; M. Plewczyński, Secygniowski (Sancygniowski, Sęcygniewski) Jakub, „Polski Słownik Biograficzny" (PSB) 1994-1995, t. XXXVI, s. 122-125.

${ }^{23}$ Zagadnienie dowodzenia oddziałami dworzan w czasach Zygmunta Starego wciąż wymaga szczegółowych studiów. Wiele wskazuje na to, że podobnie jak w wojskach zaciężnych, miało ono kilkustopniową strukturę, gdzie tylko urzędnik najwyższy stopniem, marszałek, czy hetman (o ile w ogóle możemy tę nazwę przyjąć dla dworu przedostatniego Jagiellona), był stabilny, na zasadzie urzędu. Zob. Z. Spieralski, Geneza i początki hetmaństwa w Polsce, SMHW 1960, t. V, s. 343-344; M. Plewczyński, Naczelne dowództwo armii koronnej w latach 1501-1572, SMHW 1991, t. XXXIII, s. 54-55; M. Ferenc, Dwór Zygmunta Augusta..., s. 25; A. Gładysz, „Służba wojskowa dworzan...”, s. 49-50.

${ }^{24}$ Jan Dobrzykowski w latach 1513-1536, Serafin Wronikowski w okresie 1507-1521, Mikołaj Smolikowski 1511-1538, Florian Bierzwieński 1508-1534. 
tylko na potrzeby działań zbrojnych w latach $1519-1521^{25}$, a część, zapewne w wyniku solidnej służby, pozostawiono w otoczeniu monarchy po zakończeniu konfliktu zbrojnego ${ }^{26}$.

Zwraca uwagę fakt pojawienia się osób o potencjalnie obcym pochodzeniu, a zatem tzw. cudzoziemców, i to stanowiących więcej niż czwartą część kadry towarzyskiej ( 4 z 15 dworzan $)^{27}$. Natomiast wobec zupełnego braku informacji nie sposób dokonać charakterystyki grupy pocztowych, która wykraczałaby poza ustalenia Marka Plewczyńskiego dotyczące wojsk zaciężnych ${ }^{28}$. Przyczyny takiego stanu rzeczy należy się dopatrywać $\mathrm{w}$ fakcie, że pocztowi nie należeli do dworu i znajdowali się poza jurysdykcją zarządzającego nim marszałka ${ }^{29}$. Z kolei o wiele łatwiej byłoby zidentyfikować umaszczenie i odmiany koni wchodzących w skład pocztów dworzan, gdyż zostały one precyzyjnie opisane na kartach wspomnianych powyżej rejestrów dworzan in equos graves (na koniach ciężkich) oraz levis armaturae (lekkozbrojnych) ${ }^{30}$.

Niestety nie dysponujemy szczegółowym opisem przebiegu działań ani marszruty obranej przez tę grupę dworzan, a jakiekolwiek analizy ograniczają się do wnioskowania na podstawie aktywności militarnej zgrupowania Secygniowskiego.

Kluczowe dla obecnego stanu wiedzy badania nad przebiegiem działań zbrojnych w ostatniej wojnie z Zakonem przeprowadził Marian Biskup. Ich finałem była monumentalna monografia Wojna Pruska ${ }^{31}$. We wspomnianej pracy odnaleźć można interesujące nas zagadnienie wypadu części wojsk hetmana Mikołaja Firleja do Prus Dolnych. Siły polskie (ok. 8 tys. ludzi) skoncentrowane od 7 lipca 1520 r. pod Braniewem narażone były na działania

${ }^{25}$ Byli to: Paweł Machała, Szumlański, Jan Dzieraźnicki, Jan Zajączek, Friedrich Sopia i książę Iwan Wiśniowiecki (dwaj ostatni byli notowani jeszcze w 1522 r.).

${ }^{26}$ Andrzej Zalucha, Strzeżowski i Jan Morawiec byli notowani w grupie dworzan konnych do 1525 r., Wiktoryn Chotecki do 1533 r., Jan Kempa do 1540 r.

${ }^{27}$ Książę Ivan Wiśniowiecki był reprezentantem możnych rodów ruskich z Wielkiego Księstwa Litewskiego. Uwagę zwracają także niemiecko brzmiące personalia Friedricha Sopii. Przydomek Jana Morawca sugeruje z kolei jego czeski rodowód, jakkolwiek warto wskazać postępującą polonizację tego rodu, podczas gdy Jan Kempa wedle tego kryterium nie zostałby zaliczony do Ślązaków, których w istocie reprezentował.

${ }^{28}$ M. Plewczyński, Skład choragwi jazdy koronnej w latach 1501-1572, SMHW 1993, t. XXXV, s. 46-55.

${ }^{29} \mathrm{Na}$ dworze królowych odpowiednikiem marszałka był ochmistrz. A. Marchwińska, Królewskie dwory żon..., s. 77-78.

${ }^{30}$ AGAD, ASK, Oddz. 85, sygn. 13-14, passim. W niniejszym szkicu pominięto kwestię zwierząt. Zostanie ona szeroko opisana w przygotowywanej publikacji.

${ }^{31}$ W ubiegłym roku ukazało się jej wznowienie w wydawnictwie Napoleon V: M. Biskup, „Wojna Pruska” czyli wojna Polski z Zakonem Krzyżackim z lat 1519-1521. U źródeł sekularyzacji Prus Krzyżackich, Oświęcim 2019. 
wojsk krzyżackich ${ }^{32}$. Już w początku lipca wielki mistrz Albrecht Hohenzollern skierował pod Pisz grupę liczącą ok. 1 tys. ludzi pod dowództwem Burcharda Sichau i Antona von Schlettstadt, którzy po krótkiej walce, 23 lipca 1520 r. zmusili załogę zamku do kapitulacji. Tego samego dnia siły krzyżackie dotarły do ziemi łomżyńskiej, rabując i paląc Kolno oraz Wąsosz i ich okolice. Krzyżacka wyprawa łupieżcza powróciła do Królewca 8 sierpnia. Jej najważniejszym osiągnięciem było zablokowanie drogi wypadowej z północnego Mazowsza na ziemie krzyżackie, za sprawą obsadzenia załogą zdobytego Pisza ${ }^{33}$.

Działania nieprzyjaciela przyczyniły się do podjęcia decyzji o wypadzie do Prus Dolnych, prowadzonym „zwłaszcza przez oddziały lekkozbrojnej konnicy i Tatarów litewskich" ${ }^{34}$. Zapewne to właśnie w szeregach tej grupy znalazła się opisana w przedstawionym źródle chorągiew nadworna. Hetman Mikołaj Firlej, zaniepokojony aktywnością krzyżacką w Prusach Dolnych oraz namawiany do podjęcia akcji ofensywnej przez biskupa warmińskiego, Fabiana Luzjańskiego, zdecydował się wysłać w zagrożony rejon grupę liczącą ok. 2 tys. konnych, głównie jazdy zaciężnej oraz litewskich Tatarów i wybranych dworzan. Ekspedycja wyruszyła z obozu w Braniewie już 21 lipca 1520 r. i po tygodniu dotarła w okolice Kętrzyna $(120 \mathrm{~km})$ i Sępopola $(90 \mathrm{~km})$, a 30 lipca osiągnęła Gierdaw (dla grupy kętrzyńskiej $35 \mathrm{~km}$, zaś dla sępopolskiej $20 \mathrm{~km}$ ), skupiając się na akcjach represyjnych i łupieżczych. Biorąc pod uwagę lekkozbrojny charakter grupy, można stwierdzić, że nie forsowano tempa marszu. Wyniosło ono przeciętnie ok. 13-17 km dziennie. Z uwagi na duże wyniszczenie okolicy kwaterowania sił głównych konieczne było zdobycie furażu, w czym nie przeszkodziły krzyżackie załogi Bartoszyc i Sępopola. 3 sierpnia grupa konna stanęła znowu w obozie pod Braniewem, przebywając w ciągu dwóch tygodni dystans ok. $300 \mathrm{~km}^{35}$. W ten sposób akcja prewencyjno-odwetowa, podjęta $\mathrm{z}$ udziałem wydzielonej grupy dworzan konnych Zygmunta I Starego, dobiegła na tym odcinku końca. Należałoby zatem zadać sobie pytanie o jej koszty, w kontekście udziału chorągwi dworskiej.

Rejestr dworzan, będący punktem wyjścia do przedstawionej analizy, stanowi źródło o charakterze skarbowo-wojskowym, będąc w istocie indeksem wypłaconego żołdu. W literaturze przyjmuje się, że służba na dworze

${ }^{32}$ Ibidem, s. $247-255$.

${ }^{33}$ Ibidem, s. 254.

${ }^{34}$ Ibidem, s. 255.

${ }^{35}$ Ibidem, s. 255-256. Ten sam scenariusz wydarzeń w zwięzły sposób opisuje M. Plewczyński, Wojny i wojskowość polska..., t. 1, s. 242-246. Z kolei starsze opracowania zupełnie pomijają aktywność na pograniczu Mazowsza i Prus grupy Secygniowskiego na przełomie lipca i sierpnia 1520 r. Zob. np. T. Korzon, Dzieje wojen i wojskowości polskiej, t. 1: Epoka przedrozbiorowa, Kraków 1912, s. 161-170. 
monarchy odbywała się co do zasady nieodpłatnie i sama w sobie stanowiła element awansu społecznego oraz drogę do kariery w wojsku, administracji, czy też dyplomacji ${ }^{36}$. Monarcha finansował natomiast pocztowych i konie z pocztów swoich dworzan, dając zwierzętom miejsce w królewskich stajniach i pokrywając wydatki na wyżywienie czy kwaterunek ${ }^{37}$. Niewykluczone, że wykazane w źródle wypłaty dla dworzan stanowią właśnie swoisty zwrot kosztów utrzymania pocztowych i koni biorących udział w rzeczonej misji. Proponowane stawki w wysokości 3 lub 5 zł na konia są pozornie stosunkowo niskie $\mathrm{w}$ porównaniu z żołdem $\mathrm{w}$ wojskach obrony potocznej, czy też wojskach zaciężnych, który na początku XVI w. wynosił odpowiednio 10 zł za konia kopijniczego, 6 zł za strzelczego i lekkiego ${ }^{38}$. Należy jednak zwrócić uwagę, że wspomniana stawka była kwartalna, tymczasem wyprawa rozliczona w przedstawionym obrachunku trwała niespełna miesiąc, a jej kulminacyjny etap zajął dokładnie dwa tygodnie (21 lipca - 3 sierpnia). Kalkulacja ta może przyczynić się do znaczącej zmiany interpretacji wysokości płac, które okażą się zbliżone, czy wręcz wyższe od standardowych.

Omówiony w niniejszym szkicu rejestr dworzan konnych wysłanych na Mazowsze latem 1520 r. pozwala doprecyzować ogólne informacje, dotyczące aktywności chorągwi nadwornej w przedstawionych działaniach wojennych, ale także spojrzeć na zagadnienie szerzej.

Niewątpliwie dworzanie konni odgrywali znaczącą rolę militarną i byli realnie wykorzystywani tak przez króla, jak i wyznaczonych przez niego wyższych dowódców, do realizacji zleconych zadań wojskowych w trakcie prowadzonych działań. Należy przy tym podkreślić, że wiele wskazuje, iż każdorazowo dobór dworzan z pocztami był doraźny i uzależniony od charakteru misji, do której ich kierowano.

Prezentowany rejestr wskazuje na potrzebę pogłębionych badań nad środowiskiem dworskim Zygmunta Starego, nie tylko pod kątem ściśle wojskowym,

${ }^{36}$ U. Borkowska, Dynastia Jagiellonów w Polsce, Warszawa 2011, s. 154; A. Gładysz, „Służba wojskowa dworzan...”, s. 245-275. Z kolei Plewczyński przyrównuje obecność „dworzan konnych” w otoczeniu ostatnich Jagiellonów do służby zaciężnej: „W zależności od liczby koni, jurgieltnicy ci pobierali żołd od króla według sporządzonych rejestrów dworskich". M. Plewczyński, Liczebność wojska polskiego za ostatnich Jagiellonów (1506-1572), SMHW 1989, t. XXXI, s. 45.

${ }^{37}$ M. Ferenc, Dwór Zygmunta Augusta..., s. 13. Sprawę utrzymania koni formalnie uregulowano znacznie później, dopiero za czasów Henryka Walezego, gdy postanowiono wypłacać dworzanom kwartalnie po 30 gr na 1 konia. Zob. Wykaz urzędów i służby dworu królewskiego w Polsce z czasów Henryka Walezego, wyd. S. Kutrzeba, Kraków 1902, s. 393, (=,Archiwum Komisji Historycznej”, t. 8).

${ }^{38}$ M. Plewczyński, Wojny i wojskowość polska..., t. 1, s. 82. 
ale także $\mathrm{w}$ aspekcie organizacyjnym, administracyjnym i finansowym ${ }^{39}$. Efekty tych dociekań z całą pewnością przyczynią się do pełniejszego zrozumienia codziennego funkcjonowania wojskowych u boku króla, ale także ukazania dworzan konnych jako społeczności w centrum władzy państwowej i społeczności dworskiej.

${ }^{39}$ Szerzej na temat systemu monetarnego w czasach zygmuntowskich zob. T. Lubomirski, Trzy rozdziały $z$ historii skarbowości w Polsce 1507-1532, Kraków 1868; A. Szelągowski, Pieniądz i przewrót cen w XVI i XVII wieku w Polsce, wyd. 2, Oświęcim 2019; A. Dylewski, Historia pieniądza na ziemiach polskich, Warszawa 2011. 
Cur[ienses] infrascripti missi ad Domi[num] Secygniowski M[a]g[ist]ro ${ }^{41}$ in Mazoviam grassante q[ui]bus dat[um] in equ[u]m per 3 flor[enorum] per 30 grossos.

$\begin{array}{lcc}\text { Dobrzykowski }^{42} & \text { sup[er] eq[u]os } & 6 \\ \text { Paweł Machało }^{43} & \text { "-"44 } & 4 \\ \text { Andrzej Załucha }^{45} & \text { „-" } & 4\end{array}$

${ }^{40}$ AGAD, ASK, Oddział 1 (Rachunki królewskie - dalej: Oddz. 1), sygn. 49: Percepta de propriis proventibus RM post racionem proxime consulam ad f[estum] s. Marg[arethe] 1519 et distributa de propriis proventibus RM... in curiensibus... atque distributa pro coquinis (dalej: sygn. 49), k. 55v. Tłum. z łaciny: „Niżej wymienieni dworzanie, posłani do Pana Secygniowskiego, kiedy mistrz plądrował na Mazowszu, którym dano na jednego konia po 3 złote po 30 groszy. [...] W sumie daje to 69 koni, z których na 57 wyliczono po 3 floreny po 30 groszy, a na pozostałe 12 koni po 5 florenów po 14 groszy, co daje 227 florenów po 30 groszy". Uprzejmie dziękuję za weryfikację transkrypcji i tłumaczenia dr Natalii Turkiewicz.

${ }^{41}$ Albrecht Hohenzollern (ur. 17 V 1490 - zm. 28 III 1568) - syn siostry Zygmunta I, Zofii Jagiellonki, i Fryderyka Hohenzollerna, Wielki Mistrz Krzyżacki. S. Bodniak, Albrecht Hohenzollern, PSB 1935, t. I, s. 48-52.

${ }^{42}$ Dobrzykowski Jan Mazurch (ur. ? - zm. ?) - dworzanin królewski 1513-1536, wyprawa moskiewska 1513 r. w 2-3 konie, dworzanin królewski 1519 r. w 5 koni, wojna pruska 1520-1521 w 5-6 koni, oblężenie Kwidzyna 12-14 III 1520 r., działania czerwiec-lipiec 1520 r., Wągrowiec wrzesień 1520 r., na Mazowszu lipiec-sierpień 1520 r., Toruń kwiecień 1521 r., dworzanin królewski 1521-1523 w 6 koni, 1523 r. w 5 koni, 1524 r. w 7 koni, 1525 r. w 5 koni, wyprawa na Podole 1530 r. w 6 koni, wyprawa na Podole 1531 r. w 6 koni, dworzanin królewski w 1533 r. w 6 koni, podkomorzy płocki 13 IV 1536 r., wojski gostyniński przed 1547 r. AGAD, ASK, Oddz. 1, sygn. 35: Regestrum Coronacionis d. Principis Sigismundi Regis Polonie, k. 56-57; sygn. 49, k. 35, 41v, 42, 44v, 47v, 55v, 61; sygn. 58: Regestrum expedicionis curiensium (dalej: sygn. 58), k. 62; sygn. 64: Racio facta de proventibus SMR privatis per Nicolaum de Schidlowiecz... RP thezaurarium AD 1529... ad AD 1531. Percepta et distributa (dalej: sygn. 64), b.p.; sygn. 67: Racio facta per me Christopherum de Schidlowiecz nomine d.olim Nicolai de eadem Schidlowiecz RP thezaurarii de peccuniarum summis de proventibus privatis pro mensa MR perceptis ac de mandato distributis (1531-1532) (dalej: sygn. 67), k. 6; sygn. 73: Regestrum perceptorum et distributorum de proventis privatis SMR (dalej: sygn. 73), k. 9; Oddz. 85, sygn. 13, k. 199v-201, 202v; sygn. 14, k. 258v-259; MRPS, cz. 4, t. 3, nr 18070; A. Gładysz, Dworzanie Zygmunta I w wojnie..., s. 65.

${ }^{43}$ Machała Paweł (ur. ? - zm. ?) - dworzanin królewski 1520 r. w 3 konie, wojna pruska 1520-1521 w 3-4 konie, działania czerwiec-lipiec 1520 r., na Mazowszu lipiec-sierpień 1520 r., Reszel sierpień 1520 r., Toruń kwiecień 1521 r. AGAD, ASK, Oddz. 1, sygn. 49, k. 40, 42, 44, 47v, 55v, 61; Oddz. 85, sygn. 13, k. 287v.

${ }^{44}$ Znak powtórzenia odnoszący się do słów „super equos” informujących o liczbie koni, z którymi służył dworzanin.

${ }^{45}$ Zalucha (Galucha) Andrzej (ur. ? - zm. ?) - dworzanin królewski 1520 r. w 4 konie, wojna pruska 1520-1521 w 4 konie, oblężenie Kwidzyna 12-14 III 1520 r., działania czerwiec-lipiec 1520 r., na Mazowszu lipiec-sierpień 1520 r., Reszel sierpień 1520 r., Wągrowiec wrzesień 1520 r., Toruń kwiecień 1521 r., dworzanin królewski 1522 r. w 2 konie, 1524-1525 


Strzeżowski ${ }^{46}$
Morawiec Junior $^{47}$
Szimileński $^{48}$
Wronikowski $^{49}$
Dzieraziński $^{50}$
Zajączek $^{51}$
Smolikowski $^{52}$

$\begin{array}{ll}\text {,-" } & 2 \\ \text {,-" } & 6 \\ \text {,-" } & 5 \\ \text {,-" } & 6 \\ \text {,-" } & 4 \\ \text {,-" } & 2 \\ \text {,-" } & 5\end{array}$

w 4 konie. AGAD, ASK, Oddz. 1, sygn. 49, k. 34v, 40, 42, 44, 47, 55v, 60v; sygn. 58, k. 62; Oddz. 85 , sygn. 14 , k. $47 \mathrm{v}-48 ; 214 \mathrm{v}-215 \mathrm{v}$.

${ }^{46}$ Strze/yżowski (ur. ? - zm. ?) - dworzanin królewski 1520 r. w 2 konie, wojna pruska 1520-1521 w 2 konie, na Mazowszu lipiec-sierpień 1520 r., działania w marcu 1521 r., dworzanin królewski 1524 r. w 3 konie, 1525 r. w 2 konie, być może rotmistrz piechoty zaciężnej na Węgrzech w 1528 r. AGAD, ASK, Oddz. 1, sygn. 49, k. 55v, 58; sygn. 58, k. 62; Oddz. 85, sygn. $14, \mathrm{k} .171 \mathrm{v}-172$.

${ }^{47}$ Morawiec Jan junior (ur. ? - zm. ?) - dworzanin królewski 1520 r. w 6 koni, wojna pruska 1520-1521 w 6 koni, na Mazowszu lipiec-sierpień 1520 r., działania w marcu 1521 r., dworzanin królewski 1523 r. w 4 konie, 1525 r. w 4 konie. AGAD, ASK, Oddz. 1, sygn. 49, k. 55v, 58; sygn. 58, k. 60; Oddz. 85, sygn. 13, k. 115; sygn. 14, k. 251v-252.

${ }^{48}$ Szumlański (Schimileński) (ur. ? - zm. ?) - dworzanin królewski 1518-1521 w 3 konie, najazd tatarski 1519 r. w 3 konie, bitwa pod Sokalem 2 VIII 1519 r., wojna pruska 1520-1521 w 4-5 koni, oblężenie Kwidzyna 12-14 III 1520 r., działania czerwiec-lipiec 1520 r., na Mazowszu lipiec-sierpień 1520 r., Reszel sierpień 1520 r., Wągrowiec wrzesień 1520 r., Toruń kwiecień 1521 r. AGAD, ASK, Oddz. 1, sygn. 49, k. 15, 34v, 40, 42, 44, 47v, 55v, 61; Oddz. 85 , sygn. 14, k. 101v-103v.

${ }^{49}$ Wronikowski Serafin (ur. ? - zm. ?) - dworzanin królewski 1507-1508 w 6 koni, wyprawa moskiewska 1508 r. w 6 koni, wyprawa mołdawska 1509 r. w 4 konie, dworzanin królewski 1516-1521 w 3 konie, chorąży sieradzki 2 I 1519 r., najazd tatarski 1519 r. w 3 konie, bitwa pod Sokalem 2 VIII 1519 r., wojna pruska 1520-1521 w 4-6 koni, oblężenie Kwidzyna 12-14 III 1520 r., działania z czerwca-lipca 1520 r., na Mazowszu lipiec-sierpień 1520 r., Reszel sierpień 1520 r., Wągrowiec wrzesień 1520 r., Toruń kwiecień 1521 r. AGAD, ASK, Oddz. 1, sygn. 21, k. 292-292v; sygn. 49, k. 14v, 35, 39v, 42, 44v, 47, 55v, 61; Oddz. 85, sygn. 14, k. 129v-131; MRPS, cz. 4, t. 2, nr 10938, 12004; A. Gładysz, Jedna, czy dwie choragwie nadworne..., s. 96.

${ }^{50}$ Dzieraźnicki/Dzieraziński Jan (ur. ? - zm. przed 23 IV 1521 r.) - dworzanin królewski 1519 r. w 2 konie, najazd tatarski 1519 r. w 2 konie, bitwa pod Sokalem 2 VIII 1519 r., dworzanin królewski 1519-1520 w 3-4 konie, wojna pruska 1520-1521 w 3-4 konie, oblężenie Kwidzyna 12-14 III 1520 r., działania z czerwca-lipca 1520 r., na Mazowszu lipiec-sierpień 1520 r., Reszel sierpień 1520 r., Wągrowiec wrzesień 1520 r. AGAD, ASK, Oddz. 1, sygn. 49, k.14v, 34v, 40v, 42, 47, 55v; Oddz. 85, sygn. 14, k. 204v-206; MRPS, cz. 4, t. 1, nr 3751.

${ }^{51}$ Zajączek Jan (ur. ? - zm. ?) - dworzanin królewski 1520 r. w 2 konie, wojna pruska 1520-1521 w 2 konie, na Mazowszu lipiec-sierpień 1520 r. AGAD, ASK, Oddz. 1, sygn. 49, k. 55v; Oddz. 85, sygn. 13, k. 237v.

${ }^{52}$ Smolikowski Mikołaj (ur. ? - zm. ?) - dworzanin królewski 1511-1538, uczestnik pojedynku z Mikołajem Turskim w 1511 r., dworzanin królewski 1518-1525 w 3 konie, najazd tatarski 1519 r. w 3 konie, bitwa pod Sokalem 2 VIII 1519 r., wojna pruska 1520-1521 w 4-5 


$\left.\begin{array}{lcl}\text { Chotecki Wiktoryn }^{53} & \text { "-" } & 4 \\ \text { Kempa }^{54} & \text { "-" } & 2 \\ \text { Bierzwieński }^{55} & \text { "- } & 7 \\ \text { Friedrich Sopia }^{56} & \text { sup[er] } & 7 \\ \text { Dux Wiśniowski }{ }^{57} & \text { „" } & 5\end{array}\right\}$ ips[os] per 5 fl post tribus

koni, na Mazowszu lipiec-sierpień 1520 r., wojna pruska 1521 r. w 2 konie, Toruń kwiecień 1521 r., dworzanin królewski 1525 r. w 4 konie, starosta wyszogrodzki, wyprawa na Podole 1530 r. w 5 koni, wysłany do zamku w Kieżmarku na Spiszu 1530-1537 w 4 konie, rotmistrz piechoty zaciężnej 1532 r., dworzanin królewski 1533 r. w 5 koni, wyprawa z Izabelą Jagiellonką na Węgry 1538 r., dworzanin królewski 1540 r. w 5 koni. AGAD, ASK, Oddz. 1, sygn. 49, k. $16,37,41,46 \mathrm{v}, 55 \mathrm{v}, 60 \mathrm{v}$; sygn. 58, k. 60v; sygn. 64, b.p.; sygn. 73, k. 7; sygn. 85: Regestrum (dalej: sygn. 85), k. 9v; Oddz. 85, sygn. 13, k. 223v-226; Elementa ad fontium editiones, t. 47: Documenta ex Archivo Regiomontano ad Poloniam Spectantia, cz. 17: 1536-1538, wyd. K. Lanckorońska, Rzym 1979, s. 89-90; Wypisy źródłowe do dziejów Wawelu, t. 3: 1516-1525, oprac. B. Przybyszewski, Kraków 1970, s. 57-58, (=„Źródła do dziejów Wawelu”, t. 5); M. Plewczyński, Materiały do zagadnienia..., cz. 3, s. 261; J. Szymczak, Ceduła na sąd boży $z 1511$ roku, „Acta Universitatis Lodziensis. Folia Historica” 1992, nr 44, s. 111-125; A. Gładysz, Dworzanie Zygmunta I w wojnie..., s. 59.

${ }^{53}$ Chotecki (Kotecki/Chodecki) Wiktoryn (ur. ? - zm. ?) - dworzanin królewski 1518-1520 w 2 konie, najazd tatarski 1519 r. w 2 konie, bitwa pod Sokalem 2 VIII 1519 r., wojna pruska 1520-1521 w 3-4 konie, na Mazowszu lipiec-sierpień 1520 r., Wągrowiec wrzesień 1520 r., Chojnice 21-30 XI 1520 r., Toruń kwiecień 1521 r., wyprawa na Podole 1530 r. w 4 konie, wyprawa na Podole 1531 r. w 4 konie, dworzanin królewski 1533 r. w 4 konie. AGAD, ASK, Oddz. 1, sygn. 49, k. 15v, 36, 51v, 55v, 60v; sygn. 64, b.p.; sygn. 67, k. 5v; sygn. 73, k. 7; Oddz. 85, sygn. 13, k. 171v-172v; A. Gładysz, Dworzanie Zygmunta I w wojnie..., s. 63.

${ }^{54}$ Campa (Kempa) Jan (ur. ? - zm. ?) - Ślązak, dworzanin królewski, najazd tatarski 1519 r. w 2 konie, bitwa pod Sokalem 2 VIII 1519 r., wojna pruska 1520-1521 w 2 konie, oblężenie Kwidzyna 12-14 III 1520 r., na Mazowszu lipiec-sierpień 1520 r., Wągrowiec wrzesień 1520 r., Chojnice 21-30 XI 1520 r., Toruń kwiecień 1521 r., dworzanin królewski 1525 r. w 4 konie, dwa glejty królewskie 1528 r., wyprawa na Podole 1530 r. w 4 konie, wyprawa na Podole 1531 r. w 4 konie, dworzanin królewski 1533 r. w 4 konie, w 1540 r. w 4 konie. AGAD, ASK, Oddz. 1, sygn. 49, k. 16, 35v, 40v, 46, 51v, 55v, 59v; sygn. 58, k. 60v; sygn. 67, k. 6v; sygn. 73 , k. 9v; sygn. 85, k. 10v; MRPS, cz. 4, t. 1, nr 5312, 5644; A. Gładysz, Dworzanie Zygmunta I $w$ wojnie..., s. 67.

${ }^{55}$ Bierzwieński Florian (ur. 1490 - zm. ok. 1547) - dworzanin królewski 1508-1534 w 3 konie, wyprawa moskiewska 1508 r. w 4 konie, wojna pruska 1520-1521 w 7 koni, na Mazowszu lipiec-sierpień 1520 r., wyprawa na Podole 1530 r. w 4 konie, wyprawa na Podole 1531 r. w 4 konie, omyłkowa nominacja na kasztelana konarskiego sieradzkiego 7 IX 1536 r., kasztelan konarski łęczycki 1541-1547. AGAD, ASK, Oddz. 1, sygn. 21, k. 59v; sygn. 49, k. 55v; sygn. 64, b.p.; sygn. 67, k. 6; MRPS, cz. 4, t. 3: nr 17542, 18231; A. Gładysz, Dworzanie Zygmunta I w wojnie..., s. 66.

${ }^{56}$ Sopia Friedrich (ur. ? - zm. ?) - dworzanin królewski 1520-1521, wojna pruska 1520-1521 w 7 koni, na Mazowszu lipiec-sierpień 1520 r., Toruń kwiecień 1521 r., dworzanin królewski 1521 r. w 7 koni, w 1522 r. w 3 konie. AGAD, ASK, Oddz. 1, sygn. 49, k. 55v, 61; Oddz. 85, sygn. 14 , k. $254 \mathrm{v}-255 \mathrm{v}$.

${ }^{57}$ Wiśniowiecki Iwan kniaź (ur. ? - zm. ?) - wojna pruska 1520-1521 w 5 koni, na Mazowszu lipiec-sierpień 1520 r., działania w marcu 1521 r., dworzanin królewski 1522 r., 
Sum[m]a facit eq[u]os $69 \mathrm{q}[\mathrm{u}]$ or [um] in $57 \mathrm{eq}[\mathrm{u}]$ os datum pro $3 \mathrm{fl}$ per gr 30 computatum et in 12 equos ultimos per $5 \mathrm{fl}$ per 14 facit totu[m] facit pro 30 gr fl $227^{58}$.

\section{Bibliografia}

\section{Archiwalia}

Archiwum Główne Akt Dawnych Archiwum Skarbu Koronnego

\section{Źródła drukowane}

Elementa ad fontium editiones, t. 47: Documenta ex Archivo Regiomontano ad Poloniam Spectantia, cz. 17: 1536-1538, wyd. K. Lanckorońska, Rzym 1979. Matricularum Regni Poloniae Summaria, wyd. T. Wierzbowski, cz. 4: Sigismundi I regis tempora complecens (1507-1548), t. 1-4, Warszawa 1917.

Wykaz urzędów i służby dworu królewskiego w Polsce z czasów Henryka Walezego, wyd. S. Kutrzeba, Kraków 1902, (=„Archiwum Komisji Historycznej”, t. 8). Wypisy źródłowe do dziejów Wawelu z archiwaliów kapitulnych i kurialnych krakowskich, t. 3: 1516-1525, oprac. B. Przybyszewski, Kraków 1970, (=„Źródła do dziejów Wawelu", t. 5).

\section{Literatura}

Biskup M., „Wojna Pruska”, czyli wojna Polski z Zakonem Krzyżackim z lat 1519-1521. U źródeł sekularyzacji Prus Krzyżackich, Oświęcim 2019.

Bodniak S., Albrecht Hohenzollern, „Polski Słownik Biograficzny” 1935, t. I.

Bołdyrew A., Uzbrojenie wczesnonowożytnego dworu książęcego w świetle rachunków dworskich. Analiza porównawcza, „Kwartalnik Historii Kultury Materialnej" 2009, nr 1.

Borkowska U., Dynastia Jagiellonów w Polsce, Warszawa 2011.

Chorążyczewski W., Przemiany organizacyjne polskiej kancelarii królewskiej u progu czasów nowożytnych, Toruń 2007.

prawdopodobnie ojciec Dymitra Wiśniowieckiego, słynnego atamana kozackiego. AGAD, ASK, Oddz. 1, sygn. 49, k. 55v, 58; I. Czamańska, Wiśniowieccy. Monografia rodu, Poznań 2007, s. 67-69.

${ }^{58}$ Analiza przedstawionych kwot pozwala obliczyć, że moneta o nominale 1 złotego liczona po 14 groszy była równowartością dwóch złotych obrachunkowych po 30 groszy. A zatem wyliczona kwota 60 zł po 14 groszy stanowi równowartość 56 złotych po 30 groszy. Należy zwrócić uwagę, że „za jednostkę liczebną już od Jana Olbrachta uchodzi złoty polski, liczący 30 groszy. [...] Z czasem jednak między prawdziwym złotym a złotym polskim powstały znaczne różnice w cenie". A. Szelągowski, Pieniądz i przewrót cen..., s. 37. Zob. A. Mikołajczyk, Obieg pieniężny w Polsce środkowej w wiekach od XVI do XVIII, , Łódź 1980, s. 11-12 (=„Acta Archeologica Lodziensia”, nr 28); H. Cywiński, Dziesięć wieków polskiego pieniądza 980-1980, Warszawa 1982, s. 61-64. 
Chorążyczewski W., Sprawy wojskowe w kancelarii królewskiej Zygmunta Starego, Warszawa 2001, (=„Miscellanea Historico-Archivistica”, t. 13).

Czamańska I., Wiśniowieccy. Monografia rodu, Poznań 2007.

Cywiński H., Dziesięć wieków polskiego pieniądza 980-1980, Warszawa 1982.

Dylewski A., Historia pieniądza na ziemiach polskich, Warszawa 2011.

Ferenc M., Dwór Zygmunta Augusta. Organizacja i ludzie, Kraków 1998.

Ferenc M., Służba wojskowa dworzan króla Zygmunta Augusta [w:] Dwór a kraj.

Między centrum a peryferiami władzy. Materiały konferencji naukowej zorganizowanej przez Zamek Królewski na Wawelu, Instytut Historii Uniwersytetu Jagiellońskiego, Instytut Historii Akademii Pedagogicznej w Krakowie w dniach 2-5 kwietnia 2001, red. R. Skowron, Kraków 2003.

Ferenc M., Uwagi o dworze litewskim Zygmunta Augusta w latach 1548-1572 [w:] Ecclesia - cultura - potestas. Studia z dziejów kultury i społeczeństwa. Księga ofiarowana Siostrze Profesor Urszuli Borkowskiej OSU, red. P. Kras, A. Januszek, A. Nalewajek, W. Polak, Kraków 2006.

Gładysz A., Armia Zygmunta Augusta w wyprawie inflanckiej 1557 roku - źródła a historiografia [w:] Broń i wojna w dziejach człowieka, red. K. Badowska, W. Wasiak, P. Łuczak, Łódź [2009].

Gładysz A., Dworzanie Zygmunta I w wojnie z Mołdawia (1530-1532) [w:] Spes in virtute. Salus in victoria, red. J. Gładysz, D. Lipska, A. Gładysz, Zabrze 2013. Gładysz A., Jedna, czy dwie choragwie nadworne Zygmunta I w kampanii mołdawskiej 1509 r.? [w:] Na z góry upatrzonych pozycjach, red. B. Międzybrodzki, M. Gajda, K. Fudalej, M. Przeperski, Zabrze 2011.

Gładysz A., Militarne aspekty funkcjonowania dworu królewskiego ostatnich Jagiellonów - stan badań i ich perspektywy [w:] Ad perpetuam rei memoriam. Jagiellonowie i ich czasy w historiografii polskiej XVI-XXI wieku, red. A. Januszek-Sieradzka, Sandomierz 2013, (=„Praeclara stirps Jagiellonica”, t. 4).

Gładysz A., Wojskowe osiagnięcia Zygmunta Augusta. Próba oceny [w:] Sigismundus Augustus Rex. Studia i szkice z dziejów panowania ostatniego Jagiellona, red. A. Januszek-Sieradzka, Sandomierz 2010, (=„Praeclara stirps Jagiellonica”, t. 2). Gładysz A., Wojskowi ulubieńcy Zygmunta Augusta, czyli o królewskich puszkarzach, ich jadłospisie i tajemniczej „skrzynce” [w:] Servitium et amicitia. Studia $z$ dziejów kariery i awansu w Polsce Jagiellonów, red. A. Januszek-Sieradzka, Sandomierz 2011, (=„Praeclara stirps Jagiellonica”, t. 3).

Gładysz A., Wyprawa pozwolska Zygmunta Augusta w 1557 roku, „Roczniki Humanistyczne" 2008, t. 56, z. 2: Historia.

Kadzik D., „Wojsko nadworne” na początku wojny Stefana Batorego z Gdańskiem $w$ świetle akt skarbowych, „Przegląd Historyczno-Wojskowy” 2017, nr 1 (259).

Kałużny J. T., U boku króla. Choragiew nadworna królów Polski u schyłku XV wieku, „Acta Universitatis Lodziensis. Folia Historica” 2019, nr 13.

Korzon T., Dzieje wojen i wojskowości polskiej, t. 1: Epoka przedrozbiorowa, Kraków 1912.

Kukiel M., Zarys historii wojskowości w Polsce, Kraków 1929. 
Lepszy K., Instrukcja wydawnicza dla źródeł historycznych od XVI w. do poł. XIX w., Warszawa 1953.

Lubomirski T., Trzy rozdziały z historii skarbowości w Polsce 1507-1532, Kraków 1868.

Marchwińska A., Królewskie dwory żon Zygmunta Augusta. Organizacja i składy osobowe, Toruń 2008.

Mikołajczyk A., Obieg pieniężny w Polsce środkowej w wiekach od XVI do XVIII, Łódź 1980, (=„Acta Archeologica Lodziensia”, nr 28).

Nalewajek A., Na królewskim dworze Jana Olbrachta, „Roczniki Humanistyczne” 2011, t. 59.

Plewczyński M., Liczebność wojska polskiego za ostatnich Jagiellonów (1506-1572), „Studia i Materiały do Historii Wojskowości” 1989, t. XXXI.

Plewczyński M., Materiały do zagadnienia liczebności i organizacji wojska polskiego w latach 1506-1572, cz. 3, „Studia i Materiały do Historii Wojskowości” 1990, t. XXXII.

Plewczyński M., Naczelne dowództwo armii koronnej w latach 1501-1572, „Studia i Materiały do Historii Wojskowości” 1991, t. XXXIII.

Plewczyński M., Secygniowski (Sancygniowski, Sęcygniewski) Jakub, „Polski Słownik Biograficzny" 1994-1995, t. XXXVI.

Plewczyński M., Skład choragwi jazdy koronnej w latach 1501-1572, „Studia i Materiały do Historii Wojskowości" 1993, t. XXXV.

Plewczyński M., Wojny i wojskowość polska XVI wieku, t. 1: Lata 1500-1548, Zabrze 2011.

Plewczyński M., Wojny i wojskowość polska XVI wieku, t. 2: Lata 1548-1575, wyd. 2, Oświęcim 2018.

Senkowski J., Rachunki królewskie i Rachunki sejmowe [w:] Archiwum Główne Akt Dawnych. Przewodnik po zespołach, wyd. 2 popr. i rozsz., red. J. Karwasińska, Warszawa 1975.

Skibniewska J., Dwór królewski Aleksandra Jagiellończyka w latach 1501-1506, Lublin 2015.

Spieralski Z., Geneza i początki hetmaństwa w Polsce, „Studia i Materiały do Historii Wojskowości” 1960, t. V.

Sułkowska-Kurasiowa I., Polska kancelaria królewska w latach 1447-1506, Wrocław 1967.

Szelągowski A., Pieniądz i przewrót cen w XVI i XVII wieku w Polsce, wyd. 2, Oświęcim 2019.

Szymczak J., Ceduła na sąd boży z 1511 roku, „Acta Universitatis Lodziensis. Folia Historica” 1992, nr 44.

Wyczański A., Między kulturą a polityką. Sekretarze królewscy Zygmunta Starego (1506-1548), Warszawa 1990.

Wyczański A., O potrzebie badań nad kancelaria Zygmunta Starego (1506-1548) [w:] Historia i archiwistyka. Ksiega pamiatkowa ku czci profesora Andrzeja Tomczaka, red. J. Dygała, S. Kalembka, M. Wojciechowski, B. Woszczyński, Warszawa 1992. 


\section{Rozprawy nieopublikowane}

Gładysz A., „Służba wojskowa dworzan Zygmunta I Starego”, Lublin 2014, mps pracy doktorskiej w Archiwum Uniwersyteckim KUL.

\section{STRESZCZENIE}

\section{Andrzej Gładysz, Rejestr dworzan konnych Zygmunta I Starego wysłanych do walki z Krzyżakami na Mazowsze latem 1520 roku}

Dworzanie konni Zygmunta I Starego, obok swojej funkcji reprezentacyjnej, stanowili nieliczny, wyćwiczony odwód, pozostający stale u boku króla, który mógł dysponować nimi w dowolnym momencie. Podczas tzw. wojny pruskiej z lat 1519-1521 liczebność tej grupy osiągnęła swoje apogeum latem 1520 r. w Toruniu (539 koni w 121 pocztach dworskich). W trakcie walk z Krzyżakami dworzanie nieustannie odpowiadali za bezpieczeństwo monarchy w miejscu jego przebywania, ale mniejsze ich grupy uczestniczyły w działaniach zbrojnych.

Analiza krótkiego fragment źródłowego, wchodzącego w skład rękopisu o sygnaturze 49 (Archiwum Główne Akt Dawnych, Archiwum Skarbu Koronnego, Oddział 1: Rachunki królewskie), pozwoliła na dokonanie szczegółowej charakterystyki niewielkiej chorągwi, złożonej z 69 koni w 15 pocztach dworzańskich, biorącej udział w walkach z rejzami krzyżackimi na północne Mazowsze na przełomie lipca i sierpnia 1520 r. Omówiono skład osobowy oddziału, charakter i wielkość pocztów, poruszono kwestię dowodzenia grupą, poniesionych na jej akcję kosztów oraz, na podstawie badań Mariana Biskupa, podano szlak bojowy.

Przedstawiony przykład można przyjąć jako punkt wyjścia do dyskusji na temat organizacji wojskowej dworu. Można przypuszczać, że z hufca dworzan konnych król lub marszałek - jako przełożony dworu - wydzielał poszczególne poczty, z których formowana była jedna lub więcej funkcjonujących równocześnie i niezależnie chorągwi nadwornych. Ich liczebność i charakterystyka były zapewne warunkowane przewidzianymi dla jednostek zadaniami.

Słowa kluczowe: dworzanie konni, Zygmunt I Stary, woja pruska, chorągiew, poczet

\section{SUM M A RY}

\section{Andrzej Gladysz, A Register of Sigismund I the Old's Mounted} Courtiers sent to Fight with the Teutonic Knights in Mazovia in the in Late July and Early August of 1520

The mounted courtiers of Sigismund I the Old, in addition to their representative function, were a small, trained reserve formation remaining permanently at the side of the king, who could issue them an order at any time. During the so-called Prussian war of 1519-1521, the size of this group reached its peak in the summer of 1520 in Torun (539 horses in 121 court detachments - pocztach dworskich). During the fights with the Teutonic Knights, the courtiers were constantly responsible for 
the safety of the monarch in his place of residence, but smaller groups took part in military actions.

The analysis of a short fragment of source material included in the manuscript no. 49 (Main Archive of Old Files, Crown Treasury Archive, Section 1: Royal Accounts) allowed to make a detailed description of a small banner, consisting of 69 horses in 15 retinues, taking part in the fight against the Teutonic Knights' plundering raids to northern Mazovia at the turn of July and August 1520. The composition of the unit and the nature and size of the retinues were discussed, as well as the issue of commanding the group, the costs incurred for its action and, based on Marian Biskup's research, the battle route was presented.

The presented example can be taken as a starting point for a discussion on the military organization of the court. It can be assumed that the king or the marshal, as the court's superior, would decide which of the individual retinues of mounted courtiers would form one or more court banners that functioned simultaneously and independently. Their number and composition were probably determined by the tasks envisaged for the units.

Keywords: mounted courtiers, Sigismund I the Old, Prussian war, banner, retinue

\section{АННОТАЦИЯ}

\section{Анджей Гладыш, Реестр конных придворных Сигизмунда I Старого, посланных на битву с тевтонскими рыцарями в Мазовии в конце июля - начале августа 1520 года}

Конные придворные Сигизмунда I Старого, помимо выполнения своей репрезентативной функции, составляли небольшой обученный резерв, который постоянно оставался на стороне короля, а тот, в свою очередь, мог воспользоваться ими в любой момент. Во время так называемой Польско-тевтонской войны 1519-1521 гг. численность этой группы достигла своего пика летом 1520 г. в Торуни (539 лошадей в 121 придворном отряде). Во время боев с тевтонскими рыцарями придворные постоянно несли ответственность за безопасность монарха в месте его пребывания, при этом меньшие их группы участвовали в военных действиях.

Анализ краткого фрагмента источника, включенного в рукопись № 49 (Центральный архив исторических документов, архив Королевского казначейства, раздел 1: королевские данные), позволил подробно описать небольшую хоругвь, состоящую из 69 лошадей в 15 придворных отрядах, которая участвовала в борьбе с тевтонскими рейзами в северную Мазовию на рубеже июля и августа 1520 г. В статье представлен личный состав части, характер и размер этих отрядов, а также поднят вопрос командования группой и затрат на ее функционирование, а на основании исследований Мариана Бискупы был указан маршрут боя.

Представленный в статье пример можно использовать как отправную точку для обсуждения военной организации двора. Можно предположить, 
что король или маршал (как настоятель двора) формировал из отряда конных придворных отдельные подразделения, из которых, в свою очередь, создавалась одна или несколько придворных хоругвей, функционирующих одновременно и независимо друг от друга. Их количество и характеристики, вероятнее всего, были обусловлены поставленными перед этими отрядами задачами.

Ключевые слова: конные придворные, Зигмунт I Старый, Польско-тевтонская война, хоругвь, отряд 